\title{
Performing the Post-Traumatic City: Treme and the Politics of Urban Space
}

\section{Dale Pattison}

\begin{abstract}
I have one message for these hoodlums . . These troops are fresh back from Iraq, well-trained, experienced, battle tested and under my orders to restore order in the streets. They have M-16s and they are locked and loaded. These troops know how to shoot and kill, and they are more than willing to do so if necessary, and I expect they will.
\end{abstract}

\section{Louisiana Governor Kathleen Blanco}

We going down to Bedford town / Iko iko unday / We gonna dance / Bout to mess around / Jockomo feena nay.

\section{"Iko Iko,” Mardi Gras Indian Traditional Song}

Louisiana Governor Kathleen Blanco's ominous declaration, publicly circulated in the days following Hurricane Katrina's landfall, betrays the militant stance adopted by the state of Louisiana and, more broadly, the federal government as authorities attempted to restore order to the streets of New Orleans. Working from this position, the state's initial response set the stage for a political project that - unsurprisingly, from Blanco's unapologetically racist remark-would mobilize state power to systematically disempower African 
Americans and the poor in New Orleans. The processes by which this response was enunciated through the space of the city would in the months and years after Hurricane Katrina drastically alter New Orleanians' relationship to their city and to the institutions responsible for their protection. The state's political stance would evolve, with the rebuilding of the city, into a posture of political exclusion, in which New Orleans would open itself to private development and thereby disenfranchise many of its lower income residents. As a result of the destruction of much of the city and the exclusionary politics that accompanied it, New Orleans would emerge from the hurricane as a site of political trauma, where residents were forced to resituate themselves in relation both to their city and to the neoliberal order that would lay claim to its urban space.

This essay examines the first season of the HBO series, Treme (2010), in order to uncover the critical relationship between trauma, performance, and urban space. Utilizing Jenny Edkins's writings on political trauma, this article positions the trauma of Hurricane Katrina not as a result of the storm or of the subsequent flooding of the city, but as a result of neoliberal strategies that placed residents of New Orleans in a psychologically precarious position in relation to the state and its institutional auxiliaries. Edkins explains, "What we call trauma takes place when the very powers that we are convinced will protect us and give us security become our tormentors: when the community of which we considered ourselves members turns against us or when our family is no longer a source of refuge but a site of danger." The well-documented injustices perpetrated against New Orleanians in the aftermath of the hurricane certainly position residents of the city as victims of the political trauma that Edkins describes. Working within this framework, David Simon and Eric Overmyer's series demonstrates, through sophisticated depictions of urban spatial practices and complex negotiations of media spaces, the opportunities for working through trauma made available by "performing" the space of the city.

The federal government's inability to execute a well-orchestrated recovery resulted in a profound destabilization of city space, one that opened the city to new modes of urban redevelopment. As the flooding subsided and reconstruction began, the city found itself within a political milieu that privileged neoliberal visions of urban progress, visions that too often politically disempowered African Americans and the poor, those affected most immediately by the destruction. This article discusses how individuals would position themselves against both material discipline in the city and the more nebulous institutional forces that continue to shape the racial, social, and political terrain of New Orleans. For many residents of the city, these institutional forces were themselves the source of lingering political trauma, and the characters and actors in Treme, by laying claim to the city as a performative space, suggest the possibility not only of reclaiming political agency in Katrina's aftermath, but also of processing psychological trauma in intimate and personally productive ways.

Even as Treme depicts its characters engaging in spatial practices that enable this working through of political trauma, it simultaneously finds itself en- 
meshed in the very modes of cultural production and consumption that it attempts to contest. In this way, the series's engagement with trauma requires a critique that moves beyond its representations within the televisual frame. I am interested, therefore, in both the ways in which the series represents resistance and the ways that, as a mediated text, Treme participates in the very modes of cultural production that it critiques. Indeed, much of the series's enticing nuance (as well as its unsettling problems) resides in the tension created between its political posture and its unavoidable presence as commodity. As criticism on the series has noted, in romanticizing New Orleans's black heritage, Treme tends to elide the city's long and complicated history of racial and social unrest and participates in forms of cultural tourism that may, in fact, embolden the neoliberal project currently underway in New Orleans. ${ }^{2}$ In granting viewers access to the "authentic" New Orleans-with its distinctive music, its gritty street culture, and its black traditions-Treme participates in the very commodification of New Orleans culture that it outwardly condemns. Nevertheless, the series's complex relationship with place - and specifically the streets and neighborhoods of New Orleans - requires viewers to consider the ways in which trauma may be represented, confronted, and processed through media representations that are grounded in place. Couching political resistance in the language of commodity, Treme suggests the possibilities of engaging in productive, tactical political resistance from within - rather than from without-a pervasive neoliberal regime.

As a text inextricably bound to mediation, then, Treme participates in the ongoing project of generating imaginaries of the city as a space of cultural exchange. In its endorsement of participatory spatial practices - in both its representations and its production - the series provides for viewers a rendition of city life that celebrates community and, specifically, performance as a means of preserving cultural memory. Building on the growing body of scholarship on the series, this essay sees both Treme's representations of performance and the "performance" enacted by the city within the televisual frame - vis-à-vis its onlocation filming, its music, and its inhabitants, many of whom appear as characters in the series - as two complementary modes of processing political trauma. In this regard, Helen Morgan Parmett's 2014 work on "media neighborhoods" and the series's "production of neighborhood as locality" provide particularly useful starting points for addressing how Treme's production elements are, in fact, intertwined with its production of space. Indeed, the performative and mediated spaces produced in the series are integral to the processing of trauma, both for the show's characters and, more broadly, for Americans attempting to establish critical distance from an expanding neoliberal project.

This patterning of political trauma as a result of institutional failure - both in the state's immediate response to the disaster and, later, in the national embrace of a neoliberal doctrine of reconstruction-is, of course, not new to the political discourse on Katrina; Spike Lee's documentary When the Levees Broke (2006) and Dave Eggers's work of narrative nonfiction Zeitoun (2009), for in- 
stance, do much to reveal the deleterious consequences of the state's failures in the aftermath of the hurricane and the related challenges involved in rebuilding the city. As a text grounded so strategically in physical place, however, Treme's engagement with the politics of urban space is valuable for understanding the ways that we confront political trauma in postdisaster, mediated urban environments. Urban space, as I will show, provides the environment in which political violence is enacted, but it also provides individuals who inhabit the city with vital opportunities for establishing themselves, politically, in space. The project of Katrina narratives, like Treme, is to position testimony, and particularly testimony as an embodied, nonverbal spatial practice, as a means of confronting political trauma. Shoshana Felman and Dori Laub explain that testimony is "a discursive practice, as opposed to pure theory. . . . As a performative speech act, testimony in effect addresses what in history is action that exceeds any substantialized significance, and what in happenings is impact that dynamically explodes any conceptual reifications and any constative delimitations." ${ }^{\prime 3}$ In this regard, the practice of testimony, insofar as it represents a "performative speech act," is much like the performative spatial practices that characters turn to in order to reclaim the politically contested urban space of New Orleans. As I will demonstrate, Treme's performative dimensions extend beyond mere representations of spatial practices, as its production strategies - which imbue the series with complex metanarratival layers - require viewers to consider performance as a strategy necessarily grounded in mediation.

Treme aired its final episode in December 2013, and although regarded favorably by critics, the series, over the course of its four seasons, was a commercial failure. This essay focuses explicitly on the show's first season, in which characters attempt to regain their psychological bearings in the aftermath of the hurricane. In its ten episodes, Simon and Overmyer provide a focused examination of psychological trauma that is lacking in the series's later seasons, and, as such, this first season proves significantly more fruitful for theorizing trauma in postdisaster urban environments. Taking place three months after the flooding of the city, the first season describes the modes by which New Orleanians attempted to reclaim the city space of New Orleans. The series gives specific attention to the neoliberal racial politics of the city, from the recent debates on public housing projects to the policing of urban spaces to the "Disneyfication" of New Orleans, and it suggests critical spatial practices that allow individuals to reclaim spaces of agency and cultural expression in their city. Utilizing the space of the city as a site for embodied performance, characters in Treme take positive steps toward reasserting themselves in the urban spaces they inhabit. Similarly, the series's casting of Katrina survivors suggests the show's concern for generating mediated performative spaces for the working through of trauma. By applying theoretical approaches equally invested in trauma studies and spatial theory, this essay demonstrates how the characters in Treme (and, indeed, its actors as well) practice space as a means of both confronting trauma and challenging the institutional projects responsible for provoking it. 


\section{Representing Resistance}

Before continuing further, it might be best to provide a brief overview of the modes of institutional discipline that emerged most prominently in New Orleans in the aftermath of the hurricane. Most examinations of the institutional failures associated with Katrina focus predominantly on the Bush administration's poor handling of the recovery effort and specifically the military presence that New Orleanians were made to endure for months after the flooding subsided. Less visible - and certainly not viewed by members of the political Right as a failure - were the neoliberal politics that shaped (and continue to shape) New Orleans culture and infrastructure. In the absence of sufficient federal funding for the rebuilding of New Orleans, the city was transformed "into a "laboratory' for experiments in free-market statism" (Peck 2010, 173) and became "the operating model of American neoliberalism" driven by neoliberal think tanks in Washington and New York. ${ }^{4}$ This plan involved "grassroots privatization," the relocating of formerly public sector markets such as education, sanitation, and debris removal to private sector nongovernmental organizations, which were often linked to the communities they were serving. Attractive on its surface, this brand of neoliberalism - lacking governmental oversight — "carries little guarantee of constitutional equal protection and often reproduces social inequalities." In this equation, African Americans and the poor are silenced by calls for industry, tourism, and profit. In his analysis of post-Katrina New Orleans, Henry Giroux identifies a new brand of biopolitics - the "biopolitics of disposability" - that emerged from the city's reconstruction. In this biopolitical relationship, he writes, "the 'free market' provides neither social protection, security, nor hope to those who are poor, sick, elderly, and marginalized by race and class." "The environment that Treme engages, then, is one in which the rapidly transforming city, seized by these neoliberal politics, continually threatens to dispossess its inhabitants.

Equally important to this essay are the ways in which this emerging brand of neoliberalism has utilized — and continues to utilize — urban space as its staging ground. As Jamie Peck, Cedric Johnson, and others have argued, cities, because of their symbolic function as outgrowths of a Keynesian economic system, represent critical spaces for the advancement of a neoliberal project. ${ }^{7}$ Weaving itself into an urban fabric founded on Keynesian visions of communal space, social services, and public housing, the neoliberal project seeks to transform urban space from the ground up, moving the practice of everyday life increasingly into the private sector. In the wake of Katrina, the streets and neighborhoods of New Orleans therefore became political sites critical to the advancement of a new, privatized, market-oriented city. For residents of the city, this, of course, resulted in a radical restructuring of urban space that would ultimately leave thousands of residents dispossessed of their right to the city. More than engaging with the trauma of the hurricane itself, Treme focuses on the psychological impact that this brand of political violence would have on the 
residents of New Orleans and the spatial tactics residents would use to reassert their symbolic claim to urban space.

Over the course of the first season's ten episodes, Overmyer and Simon link these neoliberal strategies with the state apparatus - the Bush administration - that would endorse neoliberalism as its foundational governing logic. ${ }^{8}$ The first season centers on the disappearance of David Brooks (Daryl Williams), an African American resident of New Orleans who was arrested for a traffic violation and held in prison in the hours before the storm hit. Beginning three months after the hurricane, the series's central narrative focuses on his sister, Ladonna (Khandi Alexander), and her attempts to locate David in a prison system that has lost track of its own inmates. In the final episodes, Ladonna learns of David's death, her brother a victim of an institutional failure that led to not only his wrongful imprisonment, but also his eventual murder. Many of the show's central characters are in some way linked to David, and his disappearance functions as the traumatic absence that the people of New Orleans are unable to confront directly. Confronting David's death requires an acknowledgment of the ways in which the state-whether through its infrastructural failures or through its politics of exclusion — betrayed its people and the principles of democracy. Following Edkins's 2003 writings, confronting this betrayal challenges the foundations of American identity, suggesting that one's citizenship does not preclude political trauma perpetrated by one's own country. Indeed, the forms of political exclusion associated with the neoliberal project in New Orleans create new categories of racialized citizenship-Giroux's "biopolitics of disposability" - that do not guarantee equal privilege or protection under the law.

In its first season, Treme takes the form of a trauma narrative; all of its action occurs in the present, three months after the hurricane, and characters are consistently unwilling to reflect on their experience of the hurricane or the evacuation. Only in the final episode, during David's funeral, does the narrative move back in time to depict his arrest and imprisonment, an event that serves as the traumatic core around which the series revolves. Adopting the structure of a trauma narrative here in the season finale, Treme underscores the processes by which victims of political trauma repress traumatic experiences, seeking to preserve what they imagine to be an intact relationship to state power. From its first scenes, Treme establishes the fundamental tensions between the state and the people of New Orleans, and particularly how these tensions manifest themselves in the city's streets. These early scenes depict soldiers and police officers monitoring the streets as New Orleanians prepare for their first secondline parade after Katrina. As the musicians and dancers in the Rebirth Brass Band prepare for the parade and begin to infiltrate the streets, almost every shot is framed by symbols of state authority: a line of uniformed soldiers, a stoic police officer, a police motorcycle, etc. In these opening scenes, Overmyer and Simon underscore the series's chief thematic concern: the tension between state power and street-level cultural performance. In later episodes, these overt sym- 
bols of state power give way to the less visible agents of neoliberal intervention, which emerge in the form of Katrina tour buses, signs condemning public housing projects, and the city's crumbling public infrastructure (the result of insufficient public funding). In shifting its focus from military discipline to these more transparent markers of a neoliberal presence, the series underscores the ways in which state and neoliberal politics jointly embedded themselves in the city's space.

As a visual counterpoint to these symbols of institutional discipline, the people of New Orleans, in these early scenes, seek to reassert their claim over their neighborhoods by utilizing city streets as performative spaces. Significantly, the season begins and ends with second-line parades, establishing this distinctly New Orleans cultural tradition as a practice of great significance both to the characters in the show and to the people of New Orleans. Second lining, which occurs every Sunday, nine months out of the year, involves a hired brass band and hundreds of dancers from the community - historically African Americans from impoverished neighborhoods but certainly not exclusive to that group - moving through the streets, stopping at designated neighborhood locales for food and alcohol, and "rolling" to the rhythm of the music. Joel Dinerstein calls it "a rolling block party, a cultural institution, a community event that carnivalizes and colonizes the public sphere, a weekly celebration of neighborhood or clan, a walkabout for urbanites." ${ }^{, 9}$ For cultural anthropologist Helen A. Regis, second lines encourage "a bodily knowing" and "transform urban space" by connecting disparate neighborhoods and communities (484). ${ }^{10}$ An outgrowth of the Congo Square dances of the nineteenth century, where slaves were permitted to play music, dance, and perform cultural traditions, second-line parades are part of a long, rich tradition of African American history in New Orleans. Even though parades require a permit costing as much as $\$ 2,000$ for a single day, police, especially in the parades following Katrina, have been known to harass participants. ${ }^{11}$ Nonetheless, many second liners, as Treme depicts, took to the streets despite the presence of Army personnel and police officers attempting to maintain order and discipline in the city. Addressing the political necessity of second lining, Dinerstein writes, "the politics of the parade were in staking a claim on the streets themselves, to literally represent ownership and intent." ${ }^{\prime 2}$ For the people of New Orleans, reclaiming the streets - which were in the process of being reconstituted by the city's neoliberal imperative - was as much a cultural tradition as it was an act of political protest.

Second lining is only one of many street-level cultural practices that Treme depicts. The anticipation, celebration, and aftermath of Mardi Gras also play a significant role in the show's narrative, as several characters see in carnival the possibility of political redemption for the city and its dispossessed inhabitants. For the same reason that the neoliberal project seeks to embed itself, through privatization and other related modes, in urban space, carnival participants recognize in the city's streets the potential for community building and the voicing 
of marginalized discourse. Furthermore, as a public space, "the street" represents a last vestige of a Keynesian/Fordist urban model devoted to fostering engagement in the public sphere. In Treme, Creighton Bernette (John Goodman), an English professor at Tulane University equally traumatized and incensed by the government's mismanagement of New Orleans' reconstruction, participates in the Krewe du Vieux, a Mardi Gras parade famous for scathing satire and political critique. Bernette's float, which features a papier-mâché rendition of Mayor Ray Nagin masturbating, offers subversive political commentary on Nagin's administration and its perceived ineptitude in the rebuilding of the city. Although Bernette's critique here and elsewhere in the series takes this position of resistance, his apparent inability to recognize the subtler machinations of neoliberal politics - and the state's investment in these politics - prevents him from emerging as a politically relevant figure. Indeed, perhaps because he myopically continues to view "the government" (and not the private interests already shaping reconstruction) as the source of New Orleans's ills, he, unable to adopt a viable political position, commits suicide in the penultimate episode. Nevertheless, Bernette's negotiation of public space reveals the series's investment in public performance as a means of contesting the politics of space.

Again exploring these spatial tactics, the series's eighth episode, "All on a Mardi Gras Day," is entirely devoted to depicting the performative and subversive dimensions of Mardi Gras; all of the show's characters dress in costume and take to the streets, transforming the city from a space of discipline into a space of play and performance. Despite the affirmative, celebratory atmosphere of the carnival, Simon and Overmyer are clear to point out that these forms of political subversion - though critical to reclaiming urban space-are temporary and that systemic power cannot be dismantled through any single act of resistance. Davis (Steve Zahn) and Annie (Lucia Micarelli), both of whom are involved in destructive romantic relationships, spend the day together and share a poignant moment at night's end. Likewise, Antoine (Wendell Pierce) and Ladonna, formerly married to one another but now divorced and in separate relationships, reunite in the waning hours of the carnival. In each case, the series's representation of Mardi Gras as a performative cultural tradition that encourages participants to challenge, critique, and dismantle hierarchies of power suggests that this tradition may provide temporary relief from the realities of the post-Katrina environment, embodied here through the characters' failing relationships in their everyday lives. As I will discuss in the final part of this essay, Simon and Overmyer's packaging of this and many other New Orleans cultural traditions is problematic in its apparent elision of the histories of political exclusion accompanying these traditions. Nonetheless, even in its idealization of the event, the series captures the important symbolic function Mardi Gras serves for New Orleanians who seek relief from the political exigencies of reconstruction. As the night comes to an end, police clear the streets, once again exerting discipline on the temporarily dynamic space of performance provided by the carnival, and characters are forced to return to reality. ${ }^{13}$ 
Even if Treme suggests that these performative practices only offer temporary relief from the politics of post-Katrina New Orleans, it is worth exploring how these spatial tactics function, as Overmyer and Simon are continually interested in addressing, through televisual representation, how characters utilize urban space to reclaim cultural traditions and thereby carve out spaces of political agency. Mikhail Bahktin's writings on the Rabelaisian carnival offer a logical starting point for this discussion. Bahktin explains, "carnival celebrate[s] temporary liberation from the prevailing truth and from the established order; it mark[s] the suspension of all hierarchical rank, privileges, norms, and prohibitions. Carnival [is] the true feast of time, the feast of becoming, change, and renewal. It [is] hostile to all that [is] immortalized and completed." ${ }^{14}$ Carnival democratizes space, challenging static ("immortalized and completed") political regimes responsible for maintaining an oppressive status quo. In using the city streets to temporarily suspend state discipline, carnival transforms "the city" (the regimented space of institutional discipline), in Henri Lefebvre's (1996) terms, into "the urban" (the free space of cultural performance), where a multiplicity of voices and subject positions democratically coexist. As individuals inhabit city space and perform cultural identity, they produce social space, dismantling, even if only temporarily, the structures that have overlaid urban space. ${ }^{15}$

"The city" and "the urban," are important to Lefebvre's writings on the production of space. Unlike "the smooth" and "the striated" in Deleuze and Guattari's writings, ${ }^{16}$ these terms emphasize the individual's role in producing space. City space, Lefebvre explains, describes the city as a physical place whose primary function is to discipline and control bodies to ensure the uninterrupted flow of capitalism. Urban space refers to the city as defined by its inhabitants, who democratically and creatively produce the space of the city through their movements and interactions within it. In short, city space refers to the city as a product of institutional regimentation, while urban space refers to the city as a product of user interaction. ${ }^{17}$ By regimenting lived spaces and defining public and private boundaries in our neighborhoods, city streets materially organize and discipline urban space. Nonetheless, individuals may use these infrastructural channels for subversive political activity and for the production of social space.

Continually confronted by figures of institutional authority responsible for upholding the city's neoliberal imperatives, the characters of Treme look to urban space as a means for cultivating political agency and physical sites of resistance. Mardi Gras and second lining provide a space that serves to counter the regimented, disciplined space of the modern metropolis and, more specifically for Treme, the post-Katrina neoliberal project underway in New Orleans. Engaging these "spatial tactics," in Michel de Certeau's words, allows the characters, if only temporarily, to symbolically and materially reclaim city space from institutional control, transforming it into a zone of creativity, spontaneity, and performance, and, equally important, a space for fostering marginalized 
discourse. De Certeau writes, "The space of the tactic is the space of the other. Thus it must play on and within a terrain imposed on it and organized by the law of a foreign power. It does not have the means to keep to itself, at a distance, in a position of withdrawal, foresight, and self-collection: it is a maneuver ... within enemy territory." ${ }^{\prime 18}$ Both of these cultural practices, insofar as they arose out of New Orleans's long, complex history of cultural and racial heterogeneity and are immediately linked to the Rabelaisian carnival, encourage dialogism and, more specifically, the beatification of the other. Occurring within the regimented space of the city, they reveal the potential for individuals to position themselves both materially (occupying physical place) and symbolically (asserting their right to the city) within and against the reconstruction project underway in New Orleans. ${ }^{19}$

\section{Rhythm as Resistance}

Part of the symbolic power of these practices rests in their temporal distancing from institutional time. Connected to tradition, these embodied performances locate meaning outside of the rigid framework of linear history and challenge the neoliberal state's attempt to discipline bodies through temporal manipulation. ${ }^{20}$ Second lining and, particularly Mardi Gras parades, whose origins in New Orleans date back to the seventeenth century, are part of a cyclical tradition reenacted every year by residents of the city that challenges these notions of institutional time. Mardi Gras Indians, in perhaps more immediate ways, reflect this concern for tradition and modes of labor that reject linear time. An integral part of New Orleans culture in the twentieth and twenty-first centuries, Mardi Gras Indians are African Americans who, in appropriating Native American, Creole, and African American traditions, have created a subculture defined by its tribal costumes and its elaborate performances, which include specific songs and dances. In Treme, Big Chief Albert Lambreaux (Clarke Peters), leader of The Guardians of the Flame, a Mardi Gras Indian Tribe, best represents this desire to uphold tradition. Upon his return to New Orleans, Lambreaux's primary motivation is to reassemble The Guardians of the Flame in time for St. Joseph's Night, when, every year, Mardi Gras Indians take to the streets, wearing the elaborate costumes they created over the past year. Obsessed with finishing their costumes on time, Lambreaux and his tribe work feverishly to uphold the tradition of the Mardi Gras Indians. ${ }^{21}$ Unlike his son, Delmond Lambreaux (Rob Brown), a successful jazz musician who is torn between his career in New York and his obligations at home, Big Chief rejects all forms of neoliberal urban progress, only concerning himself with rebuilding his tribe and piecing together his community. For Lambreaux, the future of New Orleans resides in rebuilding the community, not the institutional infrastructure of the city, which is in the process of being reshaped by neoliberalism; the culture of the Mardi Gras Indians, in its reliance on cyclical traditions and its 
emphasis on process rather than outcomes, helps to accomplish this revitalizing of community.

Equally important is the Mardi Gras Indians' interest in asserting their presence in urban space. As mentioned above, once a year, on St. Joseph's Night, the Mardi Gras Indians infiltrate city space, moving through neighborhoods in tribal procession, chanting and playing traditional music. Like the parades discussed earlier, this spatial practice generates dynamic situations in an otherwise static city space. However, unlike second-line parades, the Mardi Gras Indians - upholding the Indian mantra "won't bow, don't know how"-refuse to purchase permits, rendering their movements through urban space at odds with institutional discipline and, therefore, politically delinquent. ${ }^{22}$ In this regard, the Indians' very presence in urban space is a challenge to institutional authority.

Music is also integral to Indian performances and, indeed, to all of the spatial practices discussed above. Pulsating through nearly every scene, music - from jazz to hip hop to traditional Indian songs - plays a central role in Simon and Overmyer's representation of New Orleans street culture. One of Treme's central conceits is that music serves as the lifeblood of New Orleans and holds the potential for cultural redemption. From its first scenes, the show demonstrates its infatuation with New Orleans music; following the secondline parade through the streets of New Orleans, Simon and Overmyer pay little attention to dialogue. Instead, viewers are treated to several minutes of street music, which ends, with the parade, at Ladonna's bar. When Antoine sits with his fellow musicians at the bar, their dialogue is barely audible above the music blaring from the jukebox. Likewise, Big Chief Lambreaux's first impulse upon returning to New Orleans is to set up a practice space for his tribe. When he finally coerces his friends to reunite The Guardians of the Flame, they play percussion and chant Indian songs in The Tavern, an abandoned bar that Lambreaux converts into a home for his tribe. Each of the characters in Treme is in some way connected to the music of New Orleans, and David Simon has been forthcoming in interviews about wanting to create "a show about music." ${ }^{23}$ As a visual and aural medium, television affords Simon the opportunity to use music not only as dressing for his episodes or as a transitional device to segue between scenes, but as a structural component of the narrative. Several characters' narrative arcs-from Lambreaux's attempts to reunite the tribe to Antoine's efforts to find work as a trombone player to Davis's recording and promotion of his antigovernment anthem "Shame, Shame, Shame"-involve bringing music back to the city.

Furthermore, the music in Treme links the disparate communities represented by the characters in the series. For instance, in the season finale, Davis plays the traditional "My Indian Red" from his DJ booth while the show's characters - each affected in his or her own way by the aftermath of the storm - are depicted in various states of psychological unrest. In this extended montage, the music functions as a nonvisual, nonlinguistic device that diegetically links cultural and racial groups; the characters featured in the montage have each been 
affected in different ways by the reconstruction of the city (or lack thereof). More than simply uniting these groups through their shared experience, however, music, and, specifically, rhythm, ties these characters to the experience of urban space. Late in his life, Henri Lefebvre began to explore a concept he introduced in his earlier writings called "rhythmanalysis." At the heart of this theory is the idea that both bodies and cities operate on rhythms; bodies function on natural rhythms (respiration, the heart, hunger and thirst, etc.), while cities - which, for Lefebvre, are inherently sites of political strife - are made up of rational, quantitative rhythms: the rhythms of the factory. ${ }^{24}$ By inscribing natural rhythms on urban space, individuals have the power to transform that space - the very lived space of the city - into an organic extension of the body. The city could therefore be seen as dynamic and alive, operating in perpetual motion and defined by the people who negotiate and inhabit its streets.

Treme's interest in representing the diverse styles of New Orleans music - many of which are products of the Congo Square convergence of African and Western music in the nineteenth century and are therefore heavily rhythmic - and how these styles work their way into the fabric of the city is worth exploring through this lens. Several episodes feature Lambreaux and his tribe performing traditional Indian songs, which are played with tambourines accompanied by call and response vocals. ${ }^{25}$ With the procession of dancers following the tribe on St. Joseph's Night, the music is meant to inspire the natural rhythms of the body. When musicians and dancers take to the streets, they bring these natural rhythms to bear on the organized rhythms of state power inscribed on city space. Furthermore, Indian music relies on "a cycle of traditional songs, of which there are fewer than twenty." ${ }^{26}$ By performing these traditional songs as part of a cycle, and by infiltrating the streets with natural rhythms, the Mardi Gras Indians suggest ways of challenging disciplinary strategies that exert control over time and space. Simon and Overmyer give significant attention to representing these practices as modes capable of challenging the neoliberal privatization of public space. When The Guardians of the Flame are stopped, in public space, by police on St. Joseph's Night, Lambreaux stands his ground, and the police, commanded by the community liaison officer, retreat to their vehicles and leave the Indians to continue their rituals. In an earlier episode, a tour bus approaches the Indians as they perform a sacred funeral ritual. Recognizing that the tourists - with their cameras and video recorders - threaten to coopt their rituals into the spectacle of Katrina tourism, Lambreaux curtly tells the bus driver to move on. In each case, Indians use performative spatial tactics to inscribe themselves on urban spaces through song and dance, creating enclaves of communal agency that implicitly challenge a neoliberal logic of private space.

Lambreaux is particularly adamant and vocal about establishing these sites of agency, and he perhaps understands this process better than any character in the series. One of Lambreaux's subnarratives concerns the federal government's plans to raze the public housing projects in New Orleans. Experiencing only minimal damage during the flooding, ${ }^{27}$ these buildings were habitable by 
January 2006 and were considered by architecture critics to be "some of the best public housing built in the United States." ${ }^{28}$ Nonetheless, the federal government, claiming that the projects were hotbeds of crime and drug use, opted to tear them down and build new government-subsidized apartments, which have only recently accepted their first inhabitants. After construction is completed, these apartments will house 3,500 fewer inhabitants than the original projects. ${ }^{29}$ Many New Orleanians were outraged over these plans, claiming that the federal government was deliberately preventing the predominantly black inhabitants of the projects from returning to the city in an attempt to decrease the percentage of Democratic voters in the city and, more generally, scale back the city's "deviant" black population.

Lambreaux, concerned with both preserving the projects and making immediate housing available to New Orleanians in exile from the city, stages a media stunt by occupying one of the condemned units in the Calliope housing project. Inviting the media to broadcast his occupation, Lambreaux remains in the unit, even as police, sensitive to the political ramifications of violently removing him from the premises, wait outside. Lambreaux's occupation of public space in these scenes is significant. Built by the federal government and a site of street-level cultural production, the projects represent a critical site for the staging of neoliberal futures; by claiming the authority - under somewhat dubious pretenses - to raze the housing projects and open the space for private investment, the neoliberal state adopts a posture that will disenfranchise the city's poor and black residents, who have been "either forgotten or repressed" within this system. ${ }^{30}$ Lambreaux thus finds himself at a critical moment in the city's history, where Keynesian urban models - rendered here by the public housing projects - will give way to neoliberal new urbanism, a design imperative that outwardly emphasizes the preservation of history, tradition, and culture within a framework of privatization. As Darwin BondGraham notes, this model tends only to address issues of race, class, and gender in abstractions that are rarely result in equitable change for lower income residents of the city. ${ }^{31}$ Lambreaux understands the symbolic implications of the standoff in the Calliope projects, and, remaining in the unit, he compels the police to use force for his removal. By peacefully occupying public space, Lambreaux embraces a position of delinquency that establishes him outside of the neoliberal order imposing itself on New Orleans. Taking to the streets on St. Joseph's Night without a public permit represents a similar transgression of state authority, and in each case, Lambreaux's body becomes politically subversive tool; his presence in space requires the state to enact physical violence to ensure his removal. Combined with his ability to use rhythm and music to colonize urban space, this ability to claim agency over space through embodiment is important to Simon and Overmyer's commentary on how power is articulated in space.

Lambreaux's understanding of the political dimensions of performance is integral to his tribe's reassertion of agency, and The Tavern provides the Indians with a performative space in which to embody their traditions. Extending be- 
yond its walls, however, the Indians utilize public space to enact cultural memory. When The Guardians of the Flame take to the streets on St. Joseph's Night, they symbolically move these practices to the public space of the city, colonizing it and disseminating the discourses of resistance into the public sphere. Second-line parades, too, "serve as important gestures of memory" in public space, particularly for black communities with complex, lineage-based social networks. ${ }^{32}$ These New Orleans traditions acquire new meanings in post-Katrina contexts, where the neoliberal project increasingly raises challenges to the logic of public space. More than merely resisting the privatization of the city, embodied performance provides a medium through which to confront political trauma resulting from this radical restructuring of the city's public spaces. In The Archive and the Repertoire, Diana Taylor describes the potential for embodied performance to "generate, record, and transmit knowledge" in ways that resist state power, which is vested in the written archive. ${ }^{33}$ Enacted in the space of the city, performance involves embodied spatial practices that cannot be recorded into archival history. Furthermore, embodied performance facilitates a culturally ameliorating confrontation with trauma. Taylor writes, "Performance protest helps survivors cope with individual and collective trauma by using it to animate political denunciation." ${ }^{34}$ Later, she explains, "In performance, behaviors and actions can be separated from the social actors performing them. These actions can be learned, enacted, and passed on to others. The transmission of traumatic experience more closely resembles 'contagion": one "catches' and embodies the burden, pain, and responsibility of past behaviors/events." ${ }^{35}$ Through this lens, the spatial tactics that Treme represents in its first seasonproducing space, embodying rhythms, etc.- are in fact intimately tied to the characters' processing of political trauma, which stems from a betrayal by both the state (in its disavowal of its own citizens) and the socially iniquitous neoliberal project it endorses.

Working through these feelings of betrayal, then, represents the chief challenge for the show's characters, and David's absent body functions as the focal point for the series's broader commentary on political trauma as a condition of life in post-Katrina New Orleans. When Ladonna dances in the second line for her brother's funeral in the season finale, her dramatic, jerky movements are an attempt to express a despair that exists outside of language, one that can be communicated only through embodied rhythms. Traumatized by the news of David's death and the circumstances surrounding it, she cannot bring herself to uncover the full dimensions of the state's role in the tragedy, but dancing in the second line, Simon and Overmyer seem to suggest, provides her with a personally productive sense of closure. Aware of the politics underlying David's death, the audience recognizes the dance as more than an expression of grief; it functions as a performance - one shared by her community of second liners - that confronts her betrayal by the state through modes that exist outside of language. Likewise, Creighton Bernette's political satire during Mardi Gras is an embodied act that, despite its humorous dimensions, reveals a deep 
frustration with the state's response to Katrina and the neoliberal project that threatens to irrevocably alter New Orleans's racial and social heterogeneity. Lambreaux embodies Indian traditions as a means of reasserting his political subjectivity, but performing these rituals in the space of the city allows him to act out the traumatic loss of New Orleans - in ways that exist beyond language - alongside those equally traumatized by the impending disappearance of community-oriented public spaces. If these tactics are situated as attempts to confront political trauma attached to Katrina, then not only are they politically empowering, but they also provide New Orleanians with important avenues for working through political trauma.

\section{Televisual Performance}

Examining Treme's representations of embodied performance provides only a partial picture of the series's complex engagement with political trauma. To gain a more complete understanding of the show's performative layers, one must analyze its televisual architectures and the contexts in which it was produced and consumed. Even as Treme offers complex commentary on the political and psychological potentials of street-level spatial practices, the series finds itself bound up in modes of commodification that repeatedly undermine its critique of an emerging neoliberal project in New Orleans's city space. As much of the criticism on the series has noted, in its romanticized representations of New Orleans cultural practices, Treme participates in the very tourist industry that threatens the communities inhabited by its characters. ${ }^{36}$ The show's representations of "authentic" New Orleans music, food, and culture are, to some extent, packaged for consumption in processes that tend to endorse neoliberal narratives concerning the city's need for a more robust tourist industry. ${ }^{37} \mathrm{In}$ this way, culture is mobilized as a neoliberal instrument justifying economic restructuring, which, in this case, will result in the inevitable erasure of entire communities in low-income, black neighborhoods. ${ }^{38}$ Ironically, within the very process that will dispossess black residents of their right to the city, race and multiculturalism are celebrated as components of a cultural milieu that makes New Orleans "unique." Writing on Treme, Helen Morgan Parmett captures the tensions present in the series and its mandate to "authentically" capture the spirit of New Orleans. She explains, "television in the current era is imagined as both a potential for the celebration of local and vernacular culture and as an economic generator for these spaces." 39 The "economic generator" in this dialectic, of course, is a neoliberal project that seeks to shape cultural representations for profit in the name of "urban progress."

Treme's representations of "authentic" cultural practices, then, cannot be addressed outside the modes of commodification that always threaten to strip these representations of their political vitality. How, for instance, does one represent second-line parades without commodifying them as cultural practices? This brand of interrogation poses significant problems for a series fundamen- 
tally concerned with establishing positions of political resistance. Perhaps, using Kevin Fox Gotham's terminology, in nostalgically recalling an imagined urban past, Treme "helps promote the invention of authenticity" 40 and thereby aligns itself with a body of narratives recycled by the neoliberal project for the purpose of bringing visitors to the city. In this way, the show's central conceit - that viewers will see the "authentic" New Orleans behind the touristic façade - seemingly cannot escape the modes of commodification that necessarily accompany highly mediated texts.

What I argue here is that Treme's mediation of performative spatial practices provides valuable metafictional layers that allow us to understand performance and political trauma in more sophisticated ways. As Joy Fuqua has written, in several moments in the series, Treme demonstrates awareness of its own mediation. Characters like Janette Desautel (Kim Dickens) and Antoine Batiste must "perform authenticity" to cultural outsiders to establish their legitimate claim to their New Orleans identities, and the show references its televisual predecessor, Frank's Place, which, too, attempted to capture the substance of everyday black life in New Orleans. Working from this position, Fuqua writes, "Treme is a text that questions, while it also locates, place in more than territorial terms; it also folds in on itself as an invitation to think about the role television plays in a history of representational displacement, of dislocation." ${ }^{\prime 1}$ One might extend this claim regarding the series's self-awareness to address its performative dimensions and, more broadly, the role of performance in the mediated environment of the twenty-first century. In its televisual representations of performative spatial practices (which are themselves "performed" by actors in staged environments around the city), the series reads performance as a gesture necessarily bound to mediation; by highlighting its "performance" of New Orleans, Treme claims rhetorical control of embodied performance as a political and psychological act, like those that, I have shown, help New Orleanians establish positions of political and psychological resistance.

From its first episode to its last, Treme's production practices - which include on-location filming and the use of local actors and crew-establish a sense of place that complicates viewers' relationships to mediated performance. Morgan Parmett's writings on "media neighborhoods" provide the foundation for this discussion. By grounding itself in the everyday lives of New Orleanians and using local resources for its production during its four years of filming, Treme created neighborhoods that were, as a result of their involvement in the show, bound to mediation. New Orleans neighborhoods, she explains, became biopolitical spaces in which the series manufactured both economic and representational dependency. Within the city's neoliberal framework, this process results in the rebuilding of neighborhoods that embrace the forms of mediation that the show provided and, conversely, a lack of attention to neighborhoods outside of the show's spheres of production and representation. ${ }^{42}$ Implicit in this logic is an argument about televisual performance as a spatial practice bound to mediation. Morgan Parmett writes, "Treme's spatial practices create new sets 
of everyday rituals and experiences that are not unhinged from the history of neighbourhood practice, but out of which is borne a new context, one in which media practices and mediatization become normal everyday experiences themselves, not disruptive of everyday life, but as everyday life itself." ${ }^{93}$ In this way, the series not only mediates the performances given by its actors, but, more significantly, it situates performance as a spatial practice inseparable from the practice of everyday life. In short, post-Katrina New Orleans, partly as a result of the show's production and partly due to the role the city plays in preserving imaginaries of multicultural urban life, emerged from the hurricane as a performative space tethered to media representation.

Viewing New Orleans as a mediated, performed space, then, complicates Treme's investment in the forms of cultural tourism that would bolster the emerging neoliberal project. In embracing performance as a spatial practice grounded in everyday life, Simon and Overmyer utilize the series as an opportunity for residents of New Orleans to "act out" political trauma. As mentioned above, many of the actors in the series claim New Orleans as their home and were immediately affected by the hurricane. Wendell Pierce, for one, is a New Orleans native and has been intimately involved in rebuilding the city's infrastructure by bringing grocery stores to neighborhoods destroyed by flooding. ${ }^{44}$ His performance in the show, alongside those of other New Orleans residents such as John Goodman, nonprofessional actors and hurricane survivors like Phyllis Montana Leblanc, and local musicians such as Kermit Ruffins, reveal an interest on the producers' part to utilize the show as a performative space for the processing of trauma. ${ }^{45}$ In Pierce's case, in particular, the celebrity he has expanded as a result of the show has given him a public platform from which to enact material change in New Orleans' neighborhoods.

Interestingly, several of these actors, including Pierce and Leblanc, appear in Spike Lee's documentary, where they bear witness to the political violence perpetrated against them. More than just providing a space for this kind of verbal testimony, Treme's performative dimensions allow survivors to "act out" their experiences in embodied practices that, according to Taylor's writings, allow for the production of cultural memory. If examined alongside the show's interest in utilizing performance as a means of contesting institutional discipline and processing political trauma, this significant creative decision offers new avenues for analysis. Indeed, the viewer's awareness of the cast's psychological proximity to the on-screen material imbues the series with traumatic dimensions that ground the show in lived, embodied reality. This tactic helps to dismantle some of the processes of cultural consumption that are, themselves, at least in part, tied to the commodification of New Orleans that the show attempts to challenge.

The series's emphasis on sound and music, too, complicates its presence within these modes of production and consumption. With its elongated musical performances, in which viewers are asked to listen to as much as watch the on-screen action, Treme's unconventional and, to some viewers, disorienting 
emphasis on music disrupts the modes of narrative structuring that characterize much mainstream television. Rather than framing its content through the visual, which is the dominant mode of consumption in the hypermediated landscape of popular culture, Treme asks viewers to inhabit aural spaces that exist, to some extent, outside of those processes fundamental to the culture industry. Utilizing music in this way generates alternative narrative rhythms that temporally displace the viewer and, perhaps, allow for a more immersive viewing experience. Indeed, inhabiting these alternative narrative structures, viewers may find it difficult to suppress their own urges to embody the rhythms - through the tapping of a toe or a bobbing of the head - as they keep time to the music. Involving the viewer in embodied performance in this subtle way, the series complicates consumption models that that situate viewers as categorically apart from performers.

In this way, then, Treme embraces performance, mediation, and commodification as features of everyday life in post-Katrina New Orleans. Like the city streets inhabited by the show's characters, the series's production offers a space conducive to the processing of political trauma in the media-saturated environment of the twenty-first century. Indeed, performance is, at its heart, a concept grounded in mediation. When Diana Taylor, for instance, discusses the performance of cultural memory, what she refers to is an embodied practice in which tradition and cultural memory are "acted out" by members of a community ${ }^{46}$ Bodies, in this equation, mediate cultural memory, linking individuals to the past. The performances in Treme function in similar ways, providing community members opportunities to "act out" their feelings of betrayal associated with the rebuilding of the city. In its willingness to embrace performance in its multivalent forms, the series offers viewers more than a touristic view of New Orleans, as it creates a media space that is simultaneously representational and performative. The series's representations of performative spatial practices - such as carnival, second-line parades, and Indian rituals - find their metafictional corollaries in the performances offered by the show's cast, who are themselves victims of political violence created by the state's willingness to endorse an exclusionary neoliberal project of urban redevelopment. Working through political trauma in an environment where traditions are commodified for profit, Simon and Overmyer seem to suggest, involves creating performative spaces from within the very media apparatus responsible for homogenizing culture on a global scale. Indeed, witnessing the series navigate "the space between cultural reproduction and theatrical production," ${ }^{37}$ viewers may find in Treme opportunities to critique a neoliberal project that mobilizes culture to embed itself in the practice of everyday urban life.

By both representing performative spatial practices and creating media spaces for the performance of cultural memory, Treme complicates arguments that too readily position the series as an instrument, if an unwilling one, of an emerging neoliberal project. The series, itself, provided spaces for New Orleanians-both those featured in the televisual frame and those watching from 
without - to perform memory and thereby reestablish themselves symbolically, politically, and psychologically in their city. That the series was a commercial failure ironically aided in the political and psychological potency created through the its performative layers; if the series had reached a wider audience, it perhaps would have succeeded in "selling" New Orleans to a viewership ready and willing to consume it. As a "failed" HBO series, Treme will perhaps be remembered more as a cultural artifact that introduced new possibilities for enacting political resistance in a media environment that all too often commodifies even as it produces. Simon and Overmyer's careful negotiation of embodied performance - both in the show's representations and in its production-makes viewers witnesses, rather than consumers, of cultural texts. Indeed, perhaps viewers taking this posture will encourage new, more politically aware cultural productions that challenge, rather than bolster, exclusionary political projects.

\section{Notes}

1. Jenny Edkins, Trauma and the Memory of Politics (New York: Cambridge University Press, 2003), 4.

2. Herman Gray, "Recovered, Reinvented, Reimagined: Treme, Television Studies and Writing New Orleans," Television \& New Media 13, no. 3 (2012): 271.

3. Shoshana Felman and Dori Laub, Testimony: Crises of Witnessing in Literature, Psychoanalysis, and History (New York: Routledge, 1992), 5.

4. Jamie Peck, Constructions of Neoliberal Reason (New York: Oxford University Press, 2010), 173, 179.

5. Cedric Johnson, "The Neoliberal Deluge," The Neoliberal Deluge: Hurricane Katrina, Late Capitalism, and the Remaking of New Orleans, ed. Cedric Johnson (Minneapolis: University of Minnesota Press, 2011). xxxiii.

6. Henry A. Giroux, Stormy Weather: Katrina and the Politics of Disposability (Boulder: Paradigm Publishers, 2006), 22.

7. Johnson, xxiv.

8. Ironically, as Jamie Peck explains, despite the Bush administration's endorsement of a neoliberal doctrine, neoliberal think tanks would frame the government's failures in the immediate aftermath of Katrina as evidence of the inefficacy of "big government" (163). In linking the Bush administration to the neoliberal doctrine it supported, Treme avoids this rhetorical trap.

9. Joel Dinerstein, "Second Lining Post-Katrina: Learning Community from the Prince of Wales Social Aid and Pleasure Club," American Quarterly 61, no. 3 (2009): 618.

10. Helen A. Regis, "Second Lines, Minstrelsy, and the Contested Landscapes of New Orleans Afro-Creole Festivals," Cultural Anthropology 14, no. 4 (1999): 480, 484. See also Matt Sakakeeny's Roll with It: Brass Bands in the Streets of New Orleans (Durham: Duke University Press, 2013), which gives specific attention to second lines and, in particular, the Rebirth Brass Band, which is featured in Treme. More than providing readers with intimate access to the lives of these New Orleans musicians, Sakakeeny's book addresses the social ills - such as poverty, violence, and drug use - that bear on African American men as they attempt to preserve their cultural traditions.

11. Dinerstein discusses the attempts on the part of the city to curtail second line parades, at times raising permits to as much as $\$ 4,000$ for a single day. Many New Orleanians interpreted this as yet another attempt to politically exclude poor, black residents of the city $(2009,633)$.

12. Dinerstein, 631 .

13. It should be noted that, in recent decades, Mardi Gras has become increasingly involved in processes of production and consumption, particularly in terms of cultural tourism. In 2009, Mardi Gras brought an estimated \$145,723,918 to the New Orleans economy, accounting for 1.61 percent of the city's gross domestic product Spindt, Paul, and Toni Weiss, "The Economic Impact of Mardi Gras Season on the New Orleans Economy and the Net Fiscal Benefit of Staging Mardi Gras for the City of New Orleans," Tulane University, 3. This certainly undercuts the subversive value of Mardi Gras as an event that destabilizes institutional structures and perhaps speaks to the processes by which all cultural performances eventually get coopted for consumption. The same could be said for Simon and Overmyer's series, which, though politically subversive, is certainly an object for mainstream cultural consumption. 
14. Mikhail Bakhtin, Rabelais and His World, trans. Helene Iswolsky (Bloomington: Indiana University Press, 1984), 10.

15. Henri Lefebvre, Writings on Cities, trans. Eleonore Kofman and Elizabeth Lebas (Cambridge, MA: Blackwell, 1996).

16. Gilles Deleuze and Félix Guattari, A Thousand Plateaus: Capitalism and Schizophrenia, trans. Brian Massumi (London: The Athlone Press, 1987).

17. Lefebvre, Writings on Cities, 103.

18. Michel De Certeau, The Practice of Everyday Life, trans. Steven Rendall (Los Angeles: University of California Press, 1988), 37.

19. Lefebvre's famous essay "The Right to the City" (1996) articulates the fundamental relationship between the individual and the city. Discussing this essay, David Harvey writes, "The right to the city is far more than the individual liberty to access urban resources: it is a right to change ourselves by changing the city. It is, moreover, a common rather than an individual right since this transformation inevitably depends upon the exercise of a collective power to reshape the processes of urbanization" "The Right to the City," New Left Review 53 (Sept./Oct. 2008): 23.

20. Michael Foucault, in Discipline and Punish, trans. Alan Sheridan (New York: Vintage Books, 1995), explains, "The disciplines, which analyse space, break up and rearrange activities, must also be understood as machinery for adding up and capitalizing time" (157). The state disciplines bodies by regimenting time, which can be seen most clearly through the operations of the factory, the barracks, etc.

21. In his essay "Mardi Gras Indians: Carnival and Counter-Narrative in Black New Orleans," Cultural Critique 10 (autumn 1988): 99-121, George Lipsitz explores the traditions at the heart of Indian culture. The process of assembling one's costume is a crucial component of this culture. Lipsitz writes, "Designing and sewing Indian suits is a year-round endeavor; as soon as one carnival ends, the Indians begin to prepare for the next one. No one wears the same suit two years in a row" (108). Joseph Roach, in "Mardi Gras Indians and Others: Genealogies of American Per- formance," Theatre Journal 44, no. 4 (1992): 461-483, explains, "The costumes should not be thought of as artifacts, but as performances in themselves" (477) and "part of a cyclical spirit that lasts year round" (VanSpanckeren 42).

22. In recent years, the NOPD - under pressure from city councilmembers interested in cultivating Indian traditions - has made efforts to accommodate tribes on St. Joseph's Night, turning a blind eye to 6 P.M. curfew laws designed to stop the Indians from taking to the streets after dark.

23. David Simon, "Interview: 'Treme' Co-Creator Post-Mortems Season One," Hitfix, June 20,2010 .

24. Henri Lefebvre, Rhythmanalysis: Space, Time and Everyday Life, trans. Stuart Elden and Gerald Moore (New York: Continuum, 2004), 9.

25. For a more detailed discussion on Mardi Gras Indian music, see Kathryn VanSpanckeren's essay "The Mardi Gras Indian Song Cycle" (1989).

26. Henri Lefebvre, Rhythmanalysis: Space, Time and Everyday Life, trans. Stuart Elden and Gerald Moore (New York: Continuum, 2004), 9. 2007).

27. Judith Browne-Dianis, "Who Exiled New Orleans' Poor?" The Washington Post (May 17,

28. Nicoli Ouroussoff, "All Fall Down," The New York Times, November 19, 2006.

29. Rick Jervis, "A Fresh Model for Housing the Poor: New Orleans Traded All Its Projects for Housing Aimed at Evicting Crime," USA Today, August 4, 2011.

30. Paul A. Passavant, "Mega-Events, the Superdome, and the Return of the Repressed," in

The Neoliberal Deluge: Hurricane Katrina, Late Capitalism, and the Remaking of New Orleans, ed. Cedric Johnson (Minneapolis: University of Minnesota Press, 2011), 118.

31. Darwin BondGraham, "The New Orleans that Race Built: Racism, Disaster, and Urban Spatial Relationships," Souls 9, no. 1 (March 2007): 13.

32. Helen A. Regis, "Blackness and the Politics of Memory in the New Orleans Second Line," American Ethnologist 28, no. 4 (2001): 756.

33. Diana Taylor, The Archive and the Repertoire: Performing Cultural Memory in the Americas (Durham: Duke University Press, 2003), 21.

34. Ibid., 165.

35. Ibid., $167-168$.

36. Wade Rathke, "Treme for Tourists: The Music of the City without the Power," Television \& New Media 13, no. 3 (2012): 265.1

37. Kevin Fox Gotham's Authentic New Orleans: Tourism, Culture, and Race in the Big Easy (2007) provides a detailed examination of the burgeoning tourist industry in New Orleans. Since the 1960 s, the city has seen a rapid increase in its tourist economy, while at the same time experiencing "dramatic losses in urban population, stagnant incomes, and persistent poverty and racial inequality" (16).

38. Eric Porter, "Jazz and Revival," American Quarterly 61, no. 3 (2009): 595.

39. Helen Morgan Parmett, "Space, Place, and New Orleans on Television: From Frank's Place to Treme," Television \& New Media 13, no. 3 (2012): 200. 
40. Kevin Fox Gotham, Authentic New Orleans: Tourism, Culture, and Race in the Big Easy (New York: New York University Press, 2007), 164.

41. Joy Fuqua, “'In New Orleans, We Might Say It Like This...': Authenticity, Place, and HBO's Treme," Television \& New Media 13, no. 3 (2012): 237.

42. Helen Morgan Parmett, "Media as a Spatial Practice: Treme and the Production of the Media Neighborhood," Continuum 28, no. 3 (April 2014): 291.

43. Ibid., 290. 2012.

44. Jane Black, "In New Orleans, an Actor Turns Grocer," The New York Times, March 6,

45. See Kevin Dowler's "Dismemberment, Repetition, and Working-Through: Keeping up in Treme," (2013), which investigates the show's investment in television media as a traumatic response to disaster, arguing that Treme produces "a kind of repetition, and perhaps also ... a potential moment of working-through" (147). See also Matt Zoller Seitz's “'Treme' Untangles the Lessons of Trauma," (2013). His article gives some attention to the traumatic dimensions of the series, but, written for a popular audience, it does not fully address the show's complex treatment of political trauma.

46. Taylor, 16.

47. Lynnell L. Thomas, "'People Want to See What Happened": Treme, Televisual Tourism, and the Racial Remapping of Post-Katrina New Orleans," Television \& New Media 13, no. 3 (2012): 214 . 